\title{
PERUBAHAN KEHIDUPAN SOSIAL EKONOMI MASYARAKAT PASCA BENCANA GEMPA 30 SEPTEMBER 2009 NAGARI GUNUNG PADANG ALAI KECAMATAN V KOTO TIMUR KABUPATEN PADANG PARIAMAN
}

\author{
Afrinel Okwita \\ Dosen Tetap Prodi Pendidikan Sejarah FKIP UNRIKA
}

\begin{abstract}
ABSTRAK
Tujuan dari penelitian ini adalah untuk (1) mendeskripsikan bentuk-bentuk perubahan kehidupan sosial ekonomi pasca bencana gempa 30 September 2009, (2) Menjelaskan dampak perubahan terhadap interaksional masyarakat Nagari Gunung Padang Alai. Pengumpulan data dilakukan dengan cara observasi, wawancara dan dokumentasi. Untuk menguji keabsahan data, peneliti melakukan trianggulasi data. Informan penelitian adalah masyarakat korban bencana gempa bumi 30 September 2009, tokoh masyarakat, pemerintah Nagari dan Kecamatan. Teknik pemilihan informan dengan cara Snowball sampling Analisis data penelitian ini dilakukan dengan menggunakan model interaktif yang dikembangkan oleh Mathew Milles Huberman. Temuan penelitian ini menunjukan terjadinya perubahan kehidupan sosial ekonomi masyarakat pasca bencana gempa 30 September 2009 ditandai dengan semakin heterogennya kehidupan sosial seperti terbentuknya kelompok baru dalam masyarakat, beragamnya matapencaharian masyarakat. Dampak perubahan menyebabkan masyarakat semakin individualisme, hubungan masyarakat semakin renggang dan lebih bersifat egois serta ketergantungan masyarakat dalam memperoleh dana bantuan gempa.
\end{abstract}

Kata Kunci: Perubahan sosial, social ekonomi, bencana gempa

\section{PENDAHULUAN}

Kehidupan sosial masyarakat senantiasa mengalami suatu perubahan. Perubahan-perubahan pada kehidupan masyarakat tersebut merupakan fenomena sosial yang sangat wajar, oleh karena setiap manusia mempunyai kepentingan yang tidak terbatas. Perubahan-perubahan akan nampak setelah tatanan sosial dan kehidupan masyarakat yang lama dapat dibandingkan dengan kehidupan yang baru (Syani, 2002:162).

Seiring dengan perkembangan zaman dan dinamika masyarakat terlihat bahwa perubahan sosial terjadi secarc nenerus. Baik itu di daerah perkotaan 
maupun pada masyarakat perdesaan. Karena itu, lebih realitas dan bermanfaat melihat perubahan sebagai melekat dalam sifat tertentu. Termasuk melekat dalam kehidupan sosial. Apakah berbicara mengenai alam fisik, sejarah manusia atau intelek manusia, ditemukan tidak ada yang tetap seperti apa, di mana dan keadaankeadaan semula, melainkan segala sesuatu selalu bergerak, terjadi dan berubah keadaannya (Lauer, 2003:10)

Kondidi-kondisi sosial yang menyebabkan terjadinya perubahan-perubahan pada aspek kehidupan sosial antara lain kondisi ekonomis, teknologi dan geografis. Perubahan ini tidak saja disebabkan oleh faktor internal, tetapi juga disebabkan oleh faktor eksternal. Seperti siklus pergerakan bumi yang dalam beberapa tahun terakhir menyebabkan sering terjadinya bencana alam. Bencana alam yang mau tidak mau tentunya mengubah tatanan kehidupan sosial masyarakat. Seperti gempa yang berkekuatan besar pada tanggal 30 September 2009 berpusat di Kabupaten Padang Pariaman.

Nagari Gunung Padang Alai merupakan salah satu daerah terparah akibat bencana alam gempa bumi. Dampak bencana gempa terlihat pada korban jiwa dan kerusakan infrastruktur, baik rumah penduduk maupun fasilitas umum lainnya. Hal ini sungguh menjadi suatu fenomena yang menyedihkan di tengah-tengah kehidupan masyarakat.

Rusaknya berbagai bangunan milik pribadi seperti rumah maupun fasilitas umum berupa sekolah, gedung-gedung pemerintahan dan fasilitas lainnya merupakan sebahagian dari kerugian fisik yang ditimbulkan oleh bencana alam gempa bumi. Hampir sebahagian besar dari bangunan-bangunan yang ada tersebut 
mengalami kerusakan parah. Gempa bumi tidak saja menyebabkan kerusakan infrasruktur, seperti bangunan (rumah) yang robuh, kerusakan pada rumah ibadah, sekolah-sekolah, jalan-jalan, dan sarana umum lainnya. Banyak diantara bangunan yang rusak parah tersebut tidak lagi dapat ditempati ataupun digunakan. Gedung pemerintah maupun perkantoran pun tidak lagi berfungsi.

Dampak gempa bumi ini juga mengakibatkan masyarakat kehilangan mata pencaharian hidup. Sebahagian masyarakat nagari Gunung Padang Alai bermata pencaharian sebagai petani, pasca bencana gempa bumi masyarakat banyak kehilangan lahan dan kebun mereka disebabkan oleh runtuhan tebing dan tertimbun tanah longsor yang mengakibatkan lahan tersebut tidak bisa diolah kembali. Kehilangan lahan, otomatis juga membuat masyarakat tidak mampu memenuhi kebutuhan hidup keluarga. Hal tersebut tidak dapat dipungkiri menyebabkan goncangan dalam kehidupan masyarakat mulai dari fisik, moril maupun materil. Kompleksnya permasalahan sosial yang terjadi dampak gempa tersebut sangat berpengaruh besar dalam kehidupan sosial ekonomi masyarakat pasca gempa.

Dalam kehidupan sosial masyarakat nagari Padang Alai hidup dengan adat istiadat sebagai norma-norma yang banyak mengatur kehidupannya, baik berupa tata cara dalam perkawinan, mengunjungi orang yang melahirkan, khitan dan penyelenggaraan kematian. Di antara sesama anggota masyarakatnya masih memiliki rasa persaudaraan, dan masyarakatnya masih dominan hidup sebagai masyarakat yang menetap di daerah ini. Dari segi pembangunan pada daerah ini terlihat masih sangat tertinggal, hal ini ditandai 7 korong dari 9 korong masih terisolir atau masih jalan tanah. Begitupun dengan pelayanan air bersih masyarakat 
masih memanfaatkan sumber mata air yang tidak ada pengelolaan (Profil nagari Gunung padang Alai 2006).

Berdasarkan grandtour yang dimulai tanggal 11 juni 2012, terlihat bahwasannya kehidupan masyarakat nagari Gunung Padang Alai telah banyak terjadi perubahan. Perubahan secara pisik terlihat bahwa pembangunan pasca bencana gempa 30 September 2009 nagari Gunung Padang Alai ini mengalami kemajuan. Pembangunan tersebut terlihat pada perbaikan pusat pelayanan umum, pusat kesehatan, sarana pendidikan yang rusak akibat bencana gempa. Selain itu pembangunan juga terlihat pada sarana pelayanan sumber air bersih dan pembangunan jalan pada daerah terisolir.

Begitupun dengan kehidupan ekonomi masyarakat tidak hanya menggantungkan hidup pada kegiatan pertanian, namun pasca bencana gempa bumi mereka telah mampu melakukan perubahan pola mata pencaharian hidup keluar sektor pertanian. Adapun pekerjaan lain yang dilakukan masyarakat adalah sebagai buruh bangunan, peternak ayam, warung, pedagang, kerajinan rumah tangga dan bengkel. Dengan beragamnya pekerjaan masyarakat kemungkinan akan berpengaruh terhadap pendapatan, pola kosumsi dan gaya hidup masyarakat (Hasil wawancara dengan Kt. Anwar 53 tahun tanggal 3 Juni 2012).

Dengan demikian masyarakat sudah bisa menerima keadaan yang rawan dengan mampu untuk bertahan hidup dan keluar dari kondisi keterpurakan. Hal ini didorong oleh kepedulian masyarakat daerah lain dan pemerintah dalam memberikan dana bantuan sehingga masyarakat bisa memenuhi kebutuhan sehariharinya dan memberi motivasi untuk berpikir lebih maju. Banyaknya para relawan 
dan masyarakat luar datang berpartisipasi pada daerah ini sangat berdampak positif bagi masyarakat nagari Gunung Padang Alai.

Pada kehidupan sosial, dampak yang terjadi pasca bencana gempa adalah semakin renggangnya hubungan dengan sesama anggota masyarakat. Masyarakat dengan adanya bencana tersebut hanya fokus kepada hubungan keluarga inti dan mengabaikan hubungan dengan keluarga luas. Dalam kehidupan sehari-hari masyarakat lebih bersifat individualis karena mereka lebih sibuk bekerja untuk memenuhi kebutuhan keluarga masing-masing.

Namun dalam hal ini konsekuensi dari dampak gempa tidak hanya membawa pengaruh pada perubahan fisik tetapi juga melahirkan perubahanperubahan dalam kehidupan sosial ekonomi bagi masyarakat disekitarnya. Di sisi lain bencana gempa juga memberi dampak positif dan negatif dengan membandingkan keadaan sebelum dan sesudah gempa, masyarakat yang dahulunya bekerja sebagai petani sekarang sudah mampu untuk bekerja diluar sektor pertanian. Berdasarkan fakta, bahwa sistem sosial dan ekonomi kalau tidak terpaksa tidak akan berubah dengan kecepatan perkembangan masyarakat. Inilah yang menjadi alasan ketertarikan peneliti untuk melakukan penelitian yang berhubungan dengan Perubahan Kehidupan Sosial Ekonomi Masyarakat Nagari Gunung Padang Alai Pasca Gempa 30 September 2009.

\section{METODE}

Penelitian ini menggunakan pendekatan kualitatif. Penelitian ini berusaha mengkaji secara mendalam tentang perubahan kehidupan sosial ekonomi 
masyarakat Nagari Gunung Padang Alai pasca bencana gempa 30 September 2009. Penelitian kualitatif adalah penelitian yang dilakukan dengan latar belakang yang wajar dan alamiah secara holistic dan berusaha melihat mencermati dan menghayati masalah yang akan diteliti sebagai fenomena yang kompleks yang harus diteliti secara menyeluruh (Maleong, 2000:6-7)

Untuk memperoleh informasi maka teknik pemilihan informannya adalah teknik Snowball sampling. Pada sampling ini, peneliti mulai dengan kelompok kecil yang untuk menunjukkan kawan masing-masing. Kemudian kawan ini diminta pula untuk menunjukkan kawan masing-masing pula dan begitu seterusnya.Data yang dikumpulkan dalam penelitian ini terdiri dari dua jenis yaitu data primer dan sekunder. Teknik yang dipakai untuk mendapatkan data adalah observasi non partisipasi dan wawancara mendalam.

Untuk memeriksa keabsahan data, peneliti melakukan triangulasi data. Cara yang dilakukan adalah dengan memberikan pertanyaan yang relatif sama terhadap informan untuk mengumpulkan data yang sama. Data dianggap valid apabila data yang diperoleh relatif sama dari semua informan yang diwawancarai. Analisis data penelitian ini dilakukan sepanjang penelitian, yaitu dengan menggunakan model interaktif yang dikembangkan oleh Mathew Milles dan Huberman (1992: 16-20) dengan tiga langkah yaitu: Reduksi data, sajian data dan menarik kesimpulan.

\section{PEMBAHASAN}

Masyarakat Nagari Gunung Padang Alai merupakan masyarakat agraris yang menggantungkan hidupnya bekerja di bidang pertanian. Bencana gempa 30 September 2009 membawa perubahan yang sangat besar terhadap kehidupan 
masyarakat. Perubahan ini tidak hanya terlihat dari aspek fisik namun juga terlihat pada aspek non fisik seperti perubahan pada kehidupan sosial dan ekonomi. Suatu perubahan yang terjadi pada masyarakat nagari Gunung Padang Alai dapat diketahui dengan melakukan pengamatan terhadap keadaan sebelum dan sesudah gempa 30 september 2009.

Adapun bentuk-bentuk perubahan kehidupan sosial masyarakat Nagari Gunung Padang Alai pasca gempa 30 September 2009 yang didapatkan oleh peneliti adalah terjadinya perubahan kehidupan sosial ekonomi masyarakat pasca bencana gempa 30 September 2009 ditandai dengan semakin heterogennya kehidupan sosial seperti terbentuknya kelompok-kelompok baru dalam masyarakat berdasarkan hubungan kepentingan saja, terjadinya perubahan status sosial masyarakat. Di bidang ekonomi, dengan keterbatasan masyarakat dalam memenuhi kebutuhan barang dan jasa menyebabkan semakin beragamnya matapencaharian masyarakat dan terbukanya kesempatan kerja sehingga terjadinya perubahan pola kehidupan sosial dan ekonomi masyarakat.

Perubahan dalam kehidupan masyarakat nagari Gunung Padang Alai merupakan proses sosial yang di alami oleh anggota masyarakat dan sistem-sistem sosial, di mana semua tingkat kehidupan masyarakat dipengaruhi oleh faktor eksternal seperti perubahan lingkungan fisik yang disebabkan bencana alam gempa bumi 30 September 2009. Sehingga meninggalkan pola kehidupan dan sistem sosial yang lama kemudian menyesuaikan diri atau menggunakan pola-pola kehidupan sistem sosial yang baru agar tercapainya suatu keseimbangan pasca bencana bencana gempa. 
Menurut teori struktural fungsional yang dikembangkan Tallcott Parsons, mengemukakan masyarakat merupakan sistem sosial yang terdiri atas bagianbagian atau elemen-elemen yang saling menyatu dalam keseimbangan. Perubahan yang terjadi pada satu bagian akan membawa perubahan pada bagian yang lain. Asumsi dasarnya adalah bahwa setiap struktur dalam sistem sosial, fungsional terhadap yang lain. Konsep tersebut mengandung pengertian bahwa semua peristiwa dan semua struktur fungsional bagi masyarakat. Masyarakat dalam teori struktural fungsional senantiasa berada dalam keadaan berubah secara berangsurangsur dengan tetap memelihara keseimbangan (equilibrium). Masyarakat dilihat dalam kondisi dinamika dalam keseimbangan.

Menurut Parsons ada empat fungsi penting yang mutlak dibutuhkan bagi semua system social, meliputi adaptasi (A), pencapaian tujuan (G), integrasi (I), dan latensi (L) atau pemeliharaan pola. Keempat Impretatif fungsional ini dikenal dengan skema AGIL, dan fungsi tersebut wajib dimilki oleh semua sistem agar tetap bertahan (survive), penjelasannya sebagai berikut (Ritzer, 2010:121):

\section{a. Adaptasi}

Adaptasi fungsi yang amat penting di sini sistem harus dapat beradaptasi dengan cara menanggulangi situasi eksternal yang gawat, dan sistem harus bisa menyesuaikan diri dengan lingkungan dan juga dapat menyesuaikan lingkungan untuk kebutuhannya. Beragamnya matapencaharian masyarakat merupakan bentuk adaptasi yang dilakukan masyarakat dalam mencapai keteraturan dalam menjalankan kehidupan pasca bencana. 
Adapun pekerjaan diluar sektor pertanian tersebut seperti bekerja menjadi buruh bangunan, penjual sayuran, beternak ayam, membuka industri rumah tangga, penjahit pakaian dan bordir, tukang ojek dan industri rumah tangga. Sehingga dibidang pekerjaan terlihat masyarakat semakin heterogen. Terbukanya kesempatan kerja bagi masyarakat karena maraknya pembangunan seperti kesempatan menjadi tukang ojek dan bagi mereka yang memiliki modal untuk membangun ruko-ruko.

b. Goal attainment

Pencapaian tujuan sangat penting, dimana sistem harus bisa mendefenisikan dan mencapai tujuan utamanya. Tujuan utama masyarakat adalah agar terpenuhi kebutuhan ekonomi keluarganya. Dalam memenuhi ekonomi pasca bencana masyarakat melakukan berbagai macam upaya seperti keterlibatan istri dalam mencari nafkah, melibatkan anak dalam membantu perekonomian.

Hal ini dilakukan agar tercapai dan terpenuhinya kebutuhan ekonomi masyarakat (fungsi ekonomi), biaya pendidikan dan kompleknya kebutuhan manusia akan barang-barang dan jasa. Bagi masyarakat saat ini pendidikan merupakan hal yang sangat penting. Dibidang pendidikan terlihat perubahan dimana masyarakat semakin memahami arti pendidikan dan memiliki keinginan terus untuk melanjutkan pendidikan anak-anak mereka ke perguruan tinggi. Apalagi melihat masyarakat sekitar yang terus berlomba menguliahkan anakanaknya ke sekolah kesehatan. Pendidikan merupakan hal yang sangat penting, di mana pendidikan adalah proses mengajar dan belajar pola-pola kelakuan 
manusia menurut apa yang diharapkan masyarakat. Berbicara mengenai pendidikan, tentu secara tidak langsung membicarakan sekolah, karena sekolah merupakan lembaga pendidikan formal.

Masyarakat nagari Gunung Padang Alai saat ini sangat menginginkan anak-anak mereka untuk bersekolah, mereka tidak ingin keadaan ekonomi pasca gempa akhirnya membuat anak-anak mereka tidak dapat bersekolah. Jadi mereka tidak menginginkan anak-anaknya di kemudian hari putus sekolah yang disebabkan faktor finansial ekonomi keluarga. Apapun akan mereka lakukan demi melanjutkan pendidikan anak-anaknya, bila perlu kalau mereka mencari pinjaman dari koperasi untuk membiayai pendidikan anak-anak mereka. Dengan pendidikan nantinya masyarakat bisa memperoleh status sosial.

Terjadinya perubahan dari status sosial masyarakat, dimana sebelum gempa masyarakat yang berkedudukan tinggi dilihat dari kepemilikan lahan sedangkan mereka yang berada di kelas bawah adalah mereka yang bekerja menjadi buruh. Namun pasca gempa terlihat bahwasannya mereka yang memiliki lahan dan buruh tani ini sama harus mencari sumber mata pencaharian baru karena dampak gempa membuat sebahagian besar lahan pertanian mereka rusak dan tidak dapat diolah lagi. Sehingga saat ini mereka yang memiliki kekayaan atau status tertinggi terlihat dari mereka yang menguasai pasar atau mereka memiliki modal.

Menurut Parsons (dalam Martono, 2011: 200) masyarakat memperkembangkan dua macam status yaitu: ascribed status yang mana lebih banyak berhubungan dengan kelahiran (turun temurun). Kedudukan tersebut 
didapatkan dalam masyarakat tanpa memperhatikan perbedaan-perbedaan kemampuan. Kemudian yang berikutnya adalah achieved status (status yang diperjuangkan) ini adalah kedudukan seseorang yang dicapai dengan usahausaha yang disengaja melalui perjuangan dan kerja keras. Status ini akan diperoleh individu sesuai dengan prestasinya dalam kehidupan masyarakat misalnya, tingkat jabatan tertentu yang dicapai melalui pendidikan, dan menjadi seorang pengusaha yang besar melalu kegigihan dan keuletanya.

Tidak diragukan lagi bahwa saluran paling penting bagi mobilitas sosial adalah pendidikan. Pendidikan dianggap sebagai sosial elevator (perangkat) yang bergerak dari kedudukan rendah ke kedudukan lebih tinggi. Pendidikan memberikan kesempatan pada seseorang untuk mendapatkan kedudukan yang relatif lebih tinggi (Soyomukti, 2010: 398).

c. Integrasi

Sebuah sistem harus mampu mengatur dan menjaga antar hubungan bagian-bagian yang menjadi komponennya, selain itu mengatur dan mengelola ketiga fungsi (AGI). Dalam bertahan hidup pasca bencana gempa masyarakat harus mampu menyesuaikan diri dengan pekerjaan dan keadaan lingkungan yang baru sehingga terciptanya integrasi sosial dalam masyarakat. Dengan beragamnya matapencaharian masyarakat tentunya akan terbentuk kelompokkelompok baru dalam masyarakat berdasarkan hubungan kepentingan seperti adanya kelompok buruh bangunan, kelompok ojek, kelompok peternak ayam dan kelompok masyarakat ekonomi kelas menengah.

d. Latensi: 
laten bearti sistem harus mampu berfungsi sebagai pemelihara pola, sebuah sistem harus memelihara dan memperbaiki motivasi pola-pola individu dan kultural. Terjadinya perubahan kehidupan sosial ekonomi masyarakat pasca bencana gempa 2009 tentunya tidak terlepas dengan nilai-nilai yang dianut bersama. Nilai sosial hanya berlaku untuk untuk suatu kelompoktertentu, ia akan berbeda dengan nilai sosial yang berlaku dalam kelompok masyarakat lain.

Tolak kur nilai sosial ditentukan dari kemanfaatan nilai itu bagi masyarakat. Bila masyarakat masih menganggap suatu nilai itu baik, maka nilai sosial itu akan tetap suatu nilai itu baik, maka nilai sosial itu akan tetap dipertahankan, seperti saat ini perempuan bekerja di luar rumah dalam mencari nafkah pemenuhan kebutuhan ekonomi ini sudah dianggap sesuatu yang wajar dan lumrah.

Sesuai dengan hal di atas Karl Marx (Martono, 2011:38) juga mengemukan struktur ekonomi adalah penggerak sistem sosial yang akan menyebabkan perubahan sosial, lingkungan ekonomi menjadi dasar segala perilaku manusia. Selanjutnya Marx menyatakan bahwa kita harus mencari penyebab perubahan di dalam cara-cara produksi masyarakat daripada ide-idenya. Marx kemudian memusatkan perhatian pada proses produksi yang dilakukan manusia.

Jadi jelas bahwasannya mekanisme utama pendorong perubahan adalah persoalan pemenuhan materi masyarakat pasca bencana gempa 30 September 2009 baik dalam biaya kebutuhan ekonomi keluarga, pendidikan dan kebutuhan barang dan jasa lain. Maka masyarakat secara terus menerus akan beradaptasi dengan kondisi sumber daya yang selalu diperbaharui oleh tuntutan hidup. Masyarakat 
nagari Gunung Padang Alai akan melakukan serangkaian usaha untuk memenuhi kebutuhan hidup keluarga dengan cara bekerja diluar sektor pertanian.

Dampak perubahan terhadap interaksi sosial masyarakat pasca bencana gempa menyebabkan hubungan masyarakat semakin renggang, masyarakat semakin individualisme, dan lebih bersifat egois. Hal ini sesuai denganperubahan dimensi interaksional menurut Martono, (2011: 7) yang mengacu pada adanya perubahan hubungan sosial dalam masyarakat. Dimensi ini meliputi:

a. Perubahan dalam frekwensi

Perubahan hubungan sosial masyarakat disebabkan oleh perubahan dalam frekwensi yaitu dengan beragamnya jenis pekerjaan yang dilakukan masyarakat pasca gempa, membuat masyarakat semakin sibuk, dan sulit untuk berkumpul tetangga maupun sanak keluarga lainnya.

b. Perubahan dalam jarak sosial

Jarak sosial merupakan salah satu penyebab terjadinya perubahan dimana pasca gempa masyarakat tidak berani tinggal di daerah rawan bencana dan mereka mencari lokasi perumahan baru sehingga terjadi perubahan lingkungan fisik atau jarak sosial mengakibatkan lokasi perumahan mereka berjauhan.

c. Perubahan perantara.

Bekerja sebagai petani tentunya masyarakat sangat membutuhkan kehadiran orang lain. Masyarakat petani cenderung membentuk kelompokkelompok dalam mengerjakan hasil pertaniannya. Namun dengan beralihnya pekerjaan masyarakat ke luar sektor pertanian sehingga mereka semakin sibuk 
dan mengabaikan hubungan dengan sesama masyarakat. Sehingga untuk bertemu dan berkumpul tetangga bahkan karib kerabat hanya pada waktu tertentu saja seperti pada saat pesta perkawinan, ataupun pada tempat kemalangan.

Kemudian masyarakat lebih bersikap invidualis dan perubahan pola pikir masyarakat dan sikap masyarakat terhadap berbagai persoalan sosial dan budaya, disekitarnya yang berakibat terhadap pola-pola pikir yang dianut oleh masyarakat (Bungin, 2006: 91). Hal ini seperti berdampak pada sikap masyarakat yang individualis dalam masyarakat karena sibuk dengan pekerjaan masing-masing dan bersikap egois khususnya dalam menerima bantuan dari pemerintah.

Dibidang pendidikan mereka sudah mulai berlomba untuk terus melanjutkan pendidikan anak-anak mereka sampai ke perguruan tinggi. Mereka menyadari bahwasannya dengan pendidikan tentunya akan berpengaruh pada cakrawala berpikir dan pandangannya akan luas. Dengan pendidikan seseorang dapat memperoleh status yang lebih tinggi dalam masyarakat.

Hal ini sesuai dengan pendapat Parson (dalam Martono, 2011: 199) melihat fungsi pendidikan bahwa sekolah merupakan miniatur bentuk masyarakat. Bagi Parsons, individu dalam masyarakat menyandang dua status, yaitu yang dinamakan ascribed status yaitu status yang diperoleh dari kelahiran dan achieved status yaitu status yang diperoleh individu melalui kerja kerja keras salah satunya melalui pendidikan. 
Pasca gempa gempa tentunya dalam upaya melangsungkan hidupnya, manusia memerlukan dan kemudahan-kemudahan dalam melakukan sesuatu untuk tetap hidup dengan baik. Mereka memerlukan bahan makanan, minuman, pakaian, obat-obatan, sarana-sarana hiburan, sarana rekreasi, serta saranasarana lainnya. Jenis dan jumlah kebutuhan tersebut setiap saat bertambah, dan semakin kompleknya kebutuhan masyarakat menyebabkan meningkatnya pola konsumtif masyarakat. Hal ini terlihat dari masyarakat pengguna sepeda motor, pemilik perabot rumah tangga karena semua itu dapat mereka peroleh dengan cara kredit.

\section{SIMPULAN DAN SARAN}

Simpulan umum dari penelitian ini adalah Bentuk perubahan kehidupan sosial ekonomi pasca bencana gempa pertama, perubahan pola kehidupan masyarakat ditandai dengan semakin memudarnya hubungan sosial. Terbentuknya kelompok-kelompok baru dalam masyarakat berdasarkan kepentingan saja karena kehidupan sosial masyarakat sudah bersifat heterogen. Masyarakat yang memiliki kedudukan tinggi tidaklah lagi mereka yang memiliki lahan pertanian yang luas namun adalah mereka yang memiliki modal. Kedua, perubahan pola kehidupan ekonomi ditandai dengan semakin beragamnya pekerjaan masyarakat.

Adapun dampak perubahan terhadap kehidupan sosial ekonomi masyarakat pasca bencana gempa yaitu: Pertama, terlihat dari kemajuan pola pikir masyarakat dimana mereka semakin membuka pola pikirnya untuk bisa membuka usaha diluar bidang pertanian untuk dapat bertahan pasca terjadinya bencana gempa, dan 
meningkatnya kesadaran masyarakat melanjutkan pendidikan ketingkat yang lebih tinggi. Kedua, masyarakat cenderung bersikap individual dan hubungan kekerabatan mereka semakin renggang kerena mereka sibuk dengan pekerjaan masing-masing. Kemudian di bidang ekonomi terlihat semakin kompleksnya kebutuhan akan barang dan jasa melahirkan prilaku konsumtif terhadap masyarakat.

Berdasarkan temuan, bahasan, dan simpulan penelitian dikemukakan beberapa saran sebagai berikut: Diharapkan kepada pemerintah tetap memberikan perhatian kepada daerah pasca bencana dengan cara meningkatkan pembangunan dan memberikan bantuan agar masyarakat dapat membuka usaha baru untuk memenuhi kebutahan hidupnya sehari-hari.

Kepada masyarakat nagari Gunung Padang Alai khususnya masyarakat yang terkena dampak gempa tentunya terus berusaha membuka kesempatan kerja untuk usaha agar dapat meningkatkan perekonomiannya. Kemudian sebagai bahan masukan bagi peneliti lain untuk melakukan penelitian lebih jauh tentang permasalahan kehidupan sosial masyarakat pasca bencana gempa. 


\section{DAFTAR RUJUKAN}

Bungin, Burhan. 2008. Penelitian Kualitatif, Komunikasi, Ekonomi, Kebijakan, Publik, dan Ilmu Sosial Lainnya. Jakarta: Kencana.

Lauer, Robert. 2003. Perspektif Tentang Perubahan Sosial. Jakarta: Rineka Cipta

Martono Nanang. 2011. Sosiologi Perubahan Sosial Prepektif Klasik, Modern, Posmodern, dan Perkolonial, Jakarta: PT Raja grafindo Persada.

Miles, Matthew B, dan A. Michael Huberman. 1992. Analisis Data Kualitatif (Terjemahan oleh Tjettjep Rohendi Rohidi). Jakarta: Universitas Indonesia.

Moleong, Lexi J. 2000. Metode Penelitian Kualitatif. Jakarta: Remaja Rosda.

Ritzer \& Goodman. 2010. Teori sosiologi dari Teori sosiologi Klasik Sampai Perkembangan Mutakhir teori Sosial Postmodern. Cetakan kelima. Jakarta.: Kreasi Wacana Offset. Profil Nagari Gunung Padang Alai Tahun 2006

Syani, Abdul. 2002. Sosiologi Skematika, Teori dan Terapan. Jakarta: Bumi Aksara. 